\title{
Potency and selectivity indices of acetone leaf extracts of nine selected South African trees against six opportunistic Enterobacteriaceae isolates from commercial chicken eggs
}

\author{
Ishaku L. Elisha ${ }^{1,2}$, Alexander R. Jambalang ${ }^{1,3}$, Francien S. Botha', Elna M Buys ${ }^{4}$, Lyndy J. McGaw
} and Jacobus N. Eloff ${ }^{*}$

\begin{abstract}
Background: The rise in antimicrobial resistance in a plethora of nosocomial and opportunistic bacterial pathogens often isolated from commercial eggs, poses a serious public health concern. The existence of these contaminants may also serve as a drawback in the current efforts of improving the well-being of immunocompromised patients. The aim of this study was to determine the efficacy of plant extracts that had good activity on Escherichia coli in previous word on pathogens isolated from eggs for possible use in combating pathogens from eggs.

Methods: Acetone leaf extracts of nine trees with good activities against Escherichia coli were tested for their in vitro antibacterial activity against six opportunistic bacterial isolates from commercial eggs (Stenotrophomonas maltophilia, Klebsiella pneumoniae, Salmonella serotype Typhimurium, Proteus mirabilis, Enterobacter cloacae and Escherichia coli) using a serial microdilution method with tetrazolium violet as indicator of growth. Cytotoxicity was determined using a tetrazolium-based colorimetric assay against Vero kidney cells, and selectivity index calculated.

Results: The MIC values range of the different extracts against Stenotrophomonas maltophilia was $0.08-0.31 \mathrm{mg} / \mathrm{ml}$, Klebsiella pneumonia 0.08-0.63 mg/ml, Salmonella ser. Typhimurium 0.08-0.63 mg/ml, Proteus mirabilis 0.02-1.25 mg/ $\mathrm{ml}$, Enterobacter cloacae $0.08-0.31 \mathrm{mg} / \mathrm{ml}$ and Escherichia coli $0.08-0.16 \mathrm{mg} / \mathrm{ml}$ respectively. Escherichia coli was the most sensitive while Proteus mirabilis was most resistant pathogen to the different test extracts, with mean MIC values of $0.08 \mathrm{mg} / \mathrm{ml}$ and $0.46 \mathrm{mg} / \mathrm{ml}$ respectively. Cremaspora triflora extracts had good activity against all the pathogenic egg isolates, with the exception of Proteus mirabilis. Maesa lanceolata and Elaeodendron croceum had the best total antibacterial activity (TAA), while generally the selectivity index of the extract was low $(\mathrm{SI}<1)$.

Conclusion: The exceptional activity of $C$. triflora extracts suggests that the plant has potential as a therapeutic agent against some members of the Enterobacteriaceae. Further pharmacological investigations may be interesting in the search for new antimicrobial leads.
\end{abstract}

Keywords: Antimicrobial, Plant extracts, Nosocomial, Opportunistic pathogens, Hens' egg isolates

\footnotetext{
* Correspondence: kobus.eloff@up.ac.za

${ }^{1}$ Phytomedicine Programme, Department of Paraclinical Sciences, Faculty of

Veterinary Science, University of Pretoria, Private Bag X04, Onderstepoort,

0110 Pretoria, South Africa

Full list of author information is available at the end of the article
} 


\section{Background}

Table or hen's eggs are affordable and rich sources of animal protein. Chicken's eggs are used as ingredients in a wide variety of foods and refreshments $[1,2]$. The rise in consumer knowledge on food safety matters has changed the general public perception of a "good egg" from mere outer shell cleanliness and physical properties to that of microbial integrity [3]. The microbial flora of the hen's egg before lay is very low [3], after which the shell gets contaminated during the laying process and from surfaces with which it makes contact [4]. As a consequence, enteric pathogens like Salmonella spp. and Escherichia coli have been isolated from the outer shells of eggs and their internal contents [5]. There are also reports of the isolation of other members of the Enterobacteriaceae, like Citrobacter spp., Enterobacter spp., Klebsiella spp., Proteus spp. Providencia spp. and Stenotrophomonas maltophilia, either from whole or cracked eggs. These pathogenic microbes are capable of causing food spoilage, and infectious diseases in consumers when introduced into the food chain $[1,5-7]$.

There is documented evidence for the development of resistance to antimicrobial agents from an array of pathogens isolated from commercial eggs, triggering serious public health threats and adding pressure to the already overburdened antibiotic resistance crisis $[1,8]$. A valid public health concern is that there might be limited active drugs available to treat infected humans, and horizontal transfer of resistant genes between animal and human bacteria may exacerbate the current antimicrobial resistant crisis [9].

One of the measures of combating the rising rates of antimicrobial resistance is the continuous search of new, safe and effective antimicrobials as alternative agents to non-effective ones [10]. Plants have been a source of medicinal agents for thousands of years and a number of contemporary drugs have been developed from natural sources. Many of these isolations were based on the uses of plant extracts in traditional medicine .

In this study, we determined the potency, efficacy and selectivity acetone leaf extracts of nine South African trees with high activity against Escherichia coli based on the unpublished $\mathrm{PhD}$ thesis of Dr E Pauw [11] against six Gram-negative enteric pathogens isolated from commercial eggs, sold in the Gauteng Province of South Africa. The activity of these extracts have also been examined against Bacillus anthracis [12].

\section{Methods}

\section{Collection of plant material, drying and storage}

Fresh leaves from nine South African medicinal plants with excellent activity against Escherichia coli were collected from the Lowveld National Botanical Garden, Pretoria National Botanical Garden and University of Pretoria Manie van der Schyff Botanical Garden. Voucher specimens were prepared and sent to the HGWJ Schweickerdt Herbarium of the University of Pretoria for storage and identification. Herewith are the plants with their voucher numbers. Bolusanthus speciosus (H. Bolus) Harms (Fabaceae, PRU 120027), Calpurnia aurea (Aiton) Benth ssp. aurea (Fabaceae, PRU 120125), Maesa lanceolata Forssk (Maesaceae PRU120125), Elaeodendron croceum (Thunb.) DC (Celastraceae, PRU 120127). Morus mesozygia Stapf ex A. Chev (Moraceae, PRU 120128), Hypericum roeperianum G.W. Schimp.ex A. Rich. var. roeperianum, (Hypericaceae, PRU 120126), Cremaspora triflora (Thonn.) K. Schum (Rubiaceae, PRU 120129), Heteromorpha arborescens (Spreng.) Chan. \& Schltdl (Apiaceae, PRU 120026), and Pittosporum viridiflorum Sims (Pittosporaceae, PRU 120025).

\section{Extraction}

Acetone (technical grade, Merck) was used as extractant in the assays, used in a ratio 1:10 ground dried leaf material to extractant. Acetone is the best choice as an extractant mainly due to its ability to extract compounds of a wide range of polarities [13], its non-toxicity to bioassay systems [14] and ease of removal from extracts. Three grams $(3.0 \mathrm{~g})$ of each leaf sample were extracted with $30 \mathrm{ml}$ acetone. The resulting suspension was vigorously shaken in $50 \mathrm{ml}$ polyester centrifuge tubes for $5 \mathrm{~min}$, and centrifuged at $4000 \mathrm{x}$ g for $10 \mathrm{~min}$ (Hettich Centrifuge, Rotofix 32A, Labotec, Johannesburg, South Africa). The extraction was repeated two more times on the marc and supernatants were decanted into preweighed glass containers after filtering through Whatman No. 1 filter paper and concentrated to dryness under a stream of cold air. The dried extracts were stored at $5{ }^{\circ} \mathrm{C}$ in tightly stoppered glass vials until use.

\section{Bacterial isolation}

The WHO standardised culture and isolation methods (gold standard) was used for bacterial isolation. This is dependent on four basic steps namely: (1) Preenrichment of samples (shell, albumin and yolk) in non-selective media-buffered peptone water (BPWSelecta-MEDIA, South Africa). (2) Enrichment of sample-broth in selective media-tetrathionate (SelectaMEDIA, South Africa). (3) Isolation of sample on selective solid agar media-xylose lysine deoxycholate (XLD-MERCK, South Africa) and (4) Confirmation of presumptive bacterial isolates using biochemical test and molecular techniques like MALDI-TOF and Polymerase Chain Reaction (PCR) $[15,16]$.

\section{Test organisms}

Microorganisms used in this study represent pathogenic species isolated from commercial hen's eggs commonly associated with nosocomial and opportunistic infections. 
The bacteria were isolated from the shell, albumin and yolk, maintained in the Phytomedicine Laboratory at the Faculty of Veterinary Science, University of Pretoria. They consisted of six Gram-negative Enterobacteriaceae strains namely Stenotrophomonas maltophilia, Escherichia coli, Enterobacter cloacae, Klebsiella pneumoniae, Proteus mirabilis, and Salmonella serotype Typhimurium. All the bacterial strains were subcultured from the original culture, stored at $-80^{\circ} \mathrm{C}$ on ceramic beads in cryoprotective media (Pro-Lab diagnostics Microbank ${ }^{\circledR}$ 20) and maintained on Müller-Hinton $(\mathrm{MH})$ agar plates at $4{ }^{\circ} \mathrm{C}$.

\section{Microdilution assay}

The bacterial cultures grown overnight were adjusted to McFarland standard 1, equivalent to $1.4 \times 10^{8} \mathrm{cfu} / \mathrm{ml}$ (Stenotrophomonas maltophilia), $3.6 \times 10^{8} \mathrm{cfu} / \mathrm{ml}$ (Proteus mirabilis), $3.9 \times 10^{8} \mathrm{cfu} / \mathrm{ml}$ (Klebsiella pneumoniae), $3.8 \times 10^{8} \mathrm{cfu} / \mathrm{ml}$ (Escherichia coli), $3.2 \times 10^{8} \mathrm{cfu} / \mathrm{ml}($ Salmonella serotype Typhimurium) and $3.6 \times 10^{8} \mathrm{cfu} / \mathrm{ml}$ (Enterobacter cloacae). The two-fold serial dilution microplate method [17] was used to determine the MIC values. Briefly, aliquots $(100 \mu \mathrm{l})$ of $10 \mathrm{mg} / \mathrm{ml}$ solutions dissolved in acetone of the crude extracts were serially diluted with distilled water in 96- well micro titre plates. A $100 \mu \mathrm{l}$ aliquot of bacterial suspension was added to each well. Sterilised distilled water and acetone were used as negative and solvent control [14], and gentamicin as a positive control against the bacteria. P-iodonitrotetrazolium (INT, $0.2 \mathrm{mg} / \mathrm{ml}$ ) $40 \mu \mathrm{l}$ was added after $24 \mathrm{~h}$ of incubation of the plant extracts with bacterial cultures at $37{ }^{\circ} \mathrm{C}$ and incubated for a further $30 \mathrm{~min}$ to $1 \mathrm{~h}$ until optimal colour development. The colourless tetrazolium salt acts as an electron acceptor and is reduced to formazan product by biologically active organisms. Tests were carried out in triplicate and each experiment was repeated three times. The MIC was recorded as the lowest concentration of the extract that inhibited bacterial growth [17].

To compare the activity of different plants not only the MIC but also the quantity extracted from the plant should be taken into account. The total activity is calculated by dividing the quantity in mg extracted from one $\mathrm{g}$ of plant material by the MIC in $\mathrm{mg} / \mathrm{ml}$.

\section{Cytotoxic activity}

The 3-(4,5-dimethylthiazol-2-yl)-2, 5-diphenyltetrazolium bromide (MTT) reduction assay [18] was used to determine the cytotoxicity of the extracts against Vero cells. The method used is described as follows in our previous publication un this journal (12): "Cells were seeded at a density of $1 \times 105$ cells $/ \mathrm{ml}(100 \mu \mathrm{l})$ in 96-well microtitre plates and incubated at $37{ }^{\circ} \mathrm{C}$ and $5 \% \mathrm{CO} 2$ in a humidified environment. After $24 \mathrm{~h}$ incubation, $100 \mu \mathrm{l}$ each of differing extract concentrations were added to the wells containing cells. Doxorubicin was used as a positive control. A suitable blank control with equivalent concentrations of acetone was also included and the plates were incubated for $48 \mathrm{~h}$ in a $\mathrm{CO} 2$ incubator.

Thereafter, the medium in each well was aspirated from the cells, cells were washed with PBS, and finally $200 \mu \mathrm{l}$ fresh medium was added to each well. Thirty microliter of MTT ( $5 \mathrm{mg} / \mathrm{ml}$ in PBS) was added to each well and the plates were incubated at $37{ }^{\circ} \mathrm{C}$ for $4 \mathrm{~h}$. The medium was aspirated from the wells and DMSO was added to solubilise the formed formazan crystals. The absorbance was measured using a BioTek Synergy microplate reader at $570 \mathrm{~nm}$. The percentage of cell growth inhibition was calculated based on a comparison with untreated cells. The selectivity index values were calculated by dividing cytotoxicity LC50 values by the MIC values in the same units $(\mathrm{mg} / \mathrm{ml}) . "$

\section{Results and Discussion}

\section{Activity of the nine acetone leaf extracts against the six} egg Enterobacteriaceae isolates

Taking cognisance of the recurring arguments by different investigators on the appropriate cut-off points for defining the strength of antimicrobial activity of plant extracts $[19,20]$. Several authors classified plants according to antimicrobial activity [21-23]. This study classified plant extracts with MIC values lower than $0.1 \mathrm{mg} / \mathrm{ml}$ as significantly active; those with MIC values $>0.1$ to $0.625 \mathrm{mg} / \mathrm{ml}$ as moderately active, and MIC $>0.625 \mathrm{mg} / \mathrm{ml}$ with weak or negligible activity.

The total activity of the extracts is a pharmacologically useful measure to compare the efficacy of different plants because it takes into account not only the antimicrobial activities but also the quantities extracted from different plants. The total activity is calculated by dividing the mass in $\mathrm{mg}$ obtained from $1 \mathrm{~g}$ of plant material by the MIC in $\mathrm{mg} / \mathrm{ml}$. The total activity of the extract is expressed in $\mathrm{ml} / \mathrm{g}$ and is the volume of solvent that can added to the extract obtained from $1 \mathrm{~g}$ of plant material that will still inhibit the growth of the specific pathogen [24].

In determining cytotoxicity, plant extracts with $\mathrm{LC}_{50}>$ $20 \mu \mathrm{g} / \mathrm{ml}$ were considered relatively non-cytotoxic. Selectivity index values of the extracts were calculated by dividing the cytotoxicity $\mathrm{LC}_{50}$ (in $\mathrm{mg} / \mathrm{ml}$ ) by MIC ( $\mathrm{mg} /$ $\mathrm{ml})$. Plant extracts with SI values $>1$ imply that the extracts are less toxic to bacteria than to the mammalian cells Plant extracts might have good activity against the test organism but if they are too cytotoxic will not be of any value. When an extract shows consistent low MIC values against different pathogens i.e. there is low selectivity, it is sensible to repeat the assays and recheck the toxicity of the extracts against different cells. If the SI value is low, it could mean that the potency observed 
against the organisms might be related to a general metabolic toxin in the extract that will affect both the targeted pathogens and the host cells [25]. There is not much incentive for continuing investigation of an extract or isolated compound with a low selectivity index. It should however, be kept in mind that in vivo efficacy and toxicity of extracts or active compounds upon administration to animals or humans may differ substantially from their in vitro properties owing to pharmacokinetic and pharmacodynamical considerations [25]. Infections with Gram-negative bacteria are of imminent concern as they are more difficult to treat and outcome is poor [26].

The tree leaf extracts investigated in this study were selected based on its high activity against $E$. coli $[11,22]$. The nine acetone extracts had varying degrees of activity against the six Gram-negative enteropathogenic bacteria isolated from eggs sold in different outlets in the Gauteng province of South Africa. The sensitivity of the pathogens to the plant extracts are discussed below.

\section{Stenotrophomonas maltophilia}

Stenotrophomonas maltophilia is increasingly recognised as an important nosocomial pathogen. Treatment challenges are due to intrinsic resistance to many antibiotics as well as concerns over toxicity of the drug of choice, co-trimoxazole [27]. S. maltophilia is recognised as the cause of skin and soft-tissue, respiratory, bloodstream and prosthetic device infections, especially in immunocompromised and critically ill patients [27]. It is therefore necessary to determine how the various extracts affect S. maltophilia isolated from eggs. Given the endemicity of HIV infection in South Africa where the infected persons are often immunocompromised, this is a growing problem in this country [28]. Ingesting improperly cooked foods from contaminated eggs could add to the disease burden, thus contributing to an increase in mortality rates. Within the limits of our literature search, this is the first report of tests carried out using the nine selected South African extracts against $S$. maltophilia. The different extracts tested against $S$. maltophilia had very promising activities with MIC values ranging from 0.08 to $0.31 \mathrm{mg} / \mathrm{ml}$ (Table 1). Cremaspora triflora, $H$. arborescens, $P$. viridiflorum, M. lanceolata and $E$. croceum had good activity against $S$. maltophilia with $\mathrm{MIC}=0.08 \mathrm{mg} / \mathrm{ml}$.

Maesa lanceolata and E. croceum extracts had high total antibacterial activity against $S$. maltophilia with TAA $=1390$ and $1125 \mathrm{ml} / \mathrm{g}$ respectively due to their low MIC values and high percentage extract yield, but they were judged as unsuitable for further investigation due their high cytotoxicity (Table 1). Maesa lanceolata extracts have high efficiency against Bacillus anthracis and may be a potential disinfectant, especially in poor communities where disinfectants are not readily available or affordable [12]. In the same manner, the potential of the extracts as decontaminants or disinfectants in hatcheries could be explored. Heteromorpha arborescens had a selectivity index of 1.01, while the rest of the extracts had SI values lower than 1 (Table 1 ). Although $H$. arborescens extracts had good a MIC and low cytotoxicity, selecting it for further investigation might be challenging due to low extract yield (Table 1). Furthermore, $H$. arborescens is genotoxic, causing both DNA damage and

Table 1 Minimum inhibitory concentration (MIC) and total antibacterial activity (TAA) and selectivity index (SI) of the nine selected acetone leaf extracts against Stenotrophomonas maltophilia, Klebsiella sp. and Salmonella serotype Typhimurium (AJ 33)

\begin{tabular}{|c|c|c|c|c|c|c|c|c|c|}
\hline \multirow[b]{2}{*}{ Plants } & \multicolumn{3}{|c|}{ Stenotrophomonas maltophilia } & \multicolumn{3}{|c|}{ Klebsiella pneumoniae } & \multicolumn{3}{|c|}{ Salmonella ser. Typhimurium (AJ 33) } \\
\hline & $\mathrm{MIC}(\mathrm{mg} / \mathrm{ml})$ & TAA (ml/g) & $\mathrm{SI}$ & $\mathrm{MIC}(\mathrm{mg} / \mathrm{ml})$ & TAA $(\mathrm{ml} / \mathrm{g})$ & $\mathrm{SI}$ & $\mathrm{MIC}(\mathrm{mg} / \mathrm{ml})$ & TAA (ml/g) & $\mathrm{SI}$ \\
\hline H. roeperianum & 0.16 & 749.8 & 0.41 & 0.16 & 749.8 & 0.41 & 0.31 & 387.0 & 0.21 \\
\hline C. triflora & 0.08 & 252.1 & 0.72 & 0.08 & 252.1 & 0.72 & 0.08 & 252.1 & 0.72 \\
\hline H. arborescens & 0.08 & 325.4 & 1.01 & 0.16 & 162.7 & 0.51 & 0.16 & 162.7 & 0.51 \\
\hline P. viridiflorum & 0.08 & 339.6 & 0.68 & 0.16 & 169.8 & 0.34 & 0.16 & 169.8 & 0.34 \\
\hline B. speciosus & 0.31 & 74.3 & 0.17 & 0.16 & 144.0 & 0.33 & 0.63 & 36.6 & 0.08 \\
\hline C. aurea & 0.16 & 179.0 & 0.09 & 0.08 & 357.9 & 0.17 & 0.16 & 179.0 & 0.09 \\
\hline M. lanceolata & 0.08 & 1390.4 & 0.03 & 0.63 & 176.6 & $0^{*}$ & 0.16 & 695.2 & 0.01 \\
\hline E. croceum & 0.08 & 1124.6 & 0.07 & 0.31 & 290.2 & 0.02 & 0.31 & 290.2 & 0.02 \\
\hline M. mesozygia & 0.16 & 115.4 & 0.25 & 0.08 & 230.8 & 0.51 & 0.31 & 59.6 & 0.13 \\
\hline Mean & 0.13 & NA & NA & 0.2 & NA & NA & 0.25 & NA & NA \\
\hline SD & 0.07 & NA & NA & 0.17 & NA & NA & 0.16 & NA & NA \\
\hline Gentamicin & 0.0008 & NA & NA & 0.0008 & NA & NA & 0.006 & NA & NA \\
\hline
\end{tabular}

NA Not applicable, AJ Alexander Jambalang, ${ }^{*} 0.004$

The SI and TAA values of the extracts was calculated from the cytotoxicity and percentage yield of the extracts results published in Elisha et al. [12] Numbers in bold font MIC $<0.1 \mathrm{mg} / \mathrm{ml}$ 
chromosomal aberrations, and has the potential of causing long-term damage in patients when administered as a medicinal preparation [29].

\section{Klebsiella pneumoniae}

Klebsiella pneumoniae is the most common Gramnegative bacteria often associated with antibiotic resistant infections [30]. Klebsiella pneumoniae is an opportunistic pathogen that infects mostly hospitalised immunocompromised patients causing bacterial pneumonia. The nasopharynx and gastrointestinal tract are its preferred predilection sites [30]. Nosocomial respiratory infections caused by Klebsiella pneumoniae (Enterobacteriaceae) have increased in recent years due to the emergence of carbapenemase-producing strains [31]. These bacteria are capable of hydrolysing carbapenems, penicillins, cephalosporins, and aztreonam [31, 32], thus severely challenging antimicrobial therapy [26]. Extracts tested against $K$. pneumoniae isolated from hen's eggs had MICs ranging from $0.08 \mathrm{mg} / \mathrm{ml}$ to $0.63 \mathrm{mg} / \mathrm{ml}$ respectively. Acetone extracts of Cremaspora triflora, Calpurnia aurea and Morus mesozygia had good MIC values against K. pneumoniae $(\mathrm{MICs}=0.08 \mathrm{mg} / \mathrm{ml})$. Hypericum roeperianum, Heteromorpha arborescens, Pittosporum viridiflorum, and Bolusanthus speciosus had moderate antibacterial activity against $K$. pneumoniae with MICs of $0.16 \mathrm{mg} / \mathrm{ml}$ for all extracts. However, M. lanceolata had weak activity with $\mathrm{MIC}=0.63 \mathrm{mg} / \mathrm{ml}$. The acetone extracts of $H$. roeperianum and $C$. aurea had total activity values of $750 \mathrm{ml} / \mathrm{g}$ and $358 \mathrm{ml} / \mathrm{g}$ respectively (Table 1 ). Other extracts did not meet the benchmark of an acceptable selectivity index, $\geq 1.0$, but $C$. triflora had comparatively the highest SI value of 0.72 (Table 1).

\section{Salmonella serotype Typhimurium}

The majority of Salmonella infections are linked to the consumption of contaminated food of animal origin such as eggs, chicken, and pork. Severe Salmonella infections often require antimicrobial therapy to aid in the elimination of the infection. There are concerns over the past three decades regarding the global emergence of multi-drug resistant phenotypes among the Salmonella serotypes such as $S$. ser. Typhimurium, $S$. ser. Enteritidis and $S$. ser. Newport [33]. Currently, there are concerns over the emergence of resistance to quinolones, fluoroquinolones or extended-spectrum cephalosporins such as ceftiofur and ceftriaxone. Reports on the occurrence of Salmonella isolates resistant to these antibiotics has increased [33]. In view of these negative developments, the acetone extracts of the nine plant species were tested against $S$. ser. Typhimurium isolated from commercial hen's eggs. The extracts presented varying degrees of activities against the pathogen. The MIC ranged from $0.08 \mathrm{mg} / \mathrm{ml}$ to $0.63 \mathrm{mg} / \mathrm{ml}$ (Table 1 ). Acetone extracts of $C$. triflora had good activity against $S$. ser. Typhimurium compared to the eight other extracts, with MIC value of $0.08 \mathrm{mg} / \mathrm{ml}$. Bolusanthus speciosus had the lowest activity with an MIC of $0.63 \mathrm{mg} / \mathrm{ml}$.

\section{Proteus mirabilis}

The antibacterial activity of the extracts against Proteus mirabilis ranged from outstanding to poor $(0.02$ to

Table 2 Minimum inhibitory concentration (MIC) and total antibacterial activity (TAA) and selectivity index (SI) of the nine selected acetone leaf extracts against Proteus mirabilis, Enterobacter cloacae and Escherichia coli

\begin{tabular}{|c|c|c|c|c|c|c|c|c|c|}
\hline \multirow[b]{2}{*}{ Plants } & \multicolumn{3}{|c|}{ Proteus mirabilis } & \multicolumn{3}{|c|}{ Enterobacter cloacae } & \multicolumn{3}{|l|}{ Escherichia coli } \\
\hline & $\mathrm{MIC}(\mathrm{mg} / \mathrm{ml})$ & TAA (ml/g) & $\mathrm{SI}$ & $\mathrm{MIC}(\mathrm{mg} / \mathrm{ml})$ & TAA (ml/g) & $\mathrm{SI}$ & MIC (mg/ml) & TAA (ml/g) & $\mathrm{SI}$ \\
\hline H. roeperianum & 0.63 & 190.4 & 0.11 & 0.31 & 387.0 & 0.21 & 0.08 & 1499.6 & 0.83 \\
\hline C. triflora & 0.63 & 32.0 & 0.09 & 0.08 & 252.1 & 0.72 & 0.08 & 252.1 & 0.72 \\
\hline H. arborescens & 0.31 & 84.0 & 0.26 & 0.16 & 162.7 & 0.51 & 0.08 & 325.4 & 1.01 \\
\hline P. viridiflorum & 0.31 & 87.6 & 0.18 & 0.16 & 169.8 & 0.34 & 0.08 & 339.6 & 0.68 \\
\hline B. speciosus & 0.63 & 36.6 & 0.08 & 0.08 & 287.9 & 0.66 & 0.08 & 287.9 & 0.66 \\
\hline C. aurea & 0.31 & 92.7 & 0.04 & 0.08 & 357.9 & 0.17 & 0.04 & 715.8 & 0.34 \\
\hline M. lanceolata & 0.02 & 5561.7 & 0.12 & 0.08 & 1390.4 & 0.03 & 0.16 & 695.2 & 0.01 \\
\hline E. croceum & 0.08 & 1124.6 & 0.07 & 0.08 & 1124.6 & 0.07 & 0.08 & 1124.6 & 0.07 \\
\hline M. mesozygia & 1.25 & 14.8 & 0.03 & 0.16 & 115.4 & 0.25 & 0.08 & 230.8 & 0.51 \\
\hline Mean & 0.46 & NA & NA & 0.13 & NA & NA & 0.08 & NA & NA \\
\hline SD & 0.35 & NA & NA & 0.07 & NA & NA & 0.03 & NA & NA \\
\hline Gentamicin & 0.0008 & NA & NA & 0.0002 & NA & NA & 0.006 & NA & NA \\
\hline
\end{tabular}

NA Not applicable.

The SI and TAA values of the extracts was calculated from the cytotoxicity and percentage yield of the extracts results published in Elisha et al. [12] Numbers in bold font $\mathrm{MIC}<0.1 \mathrm{mg} / \mathrm{ml}$ 
$1.25 \mathrm{mg} / \mathrm{ml}$ ). Proteus mirabilis had the highest and lowest sensitivity to some of the extracts (Table 2). For example, the extracts of $M$. lanceolata and E. croceum had very good activities ( $\mathrm{MIC}=0.02 \mathrm{mg} / \mathrm{ml}$ and $0.08 \mathrm{mg} / \mathrm{ml}$ respectively), while the extracts of $M$. mesozygia had the lowest activity with an MIC of $1.25 \mathrm{mg} / \mathrm{ml}$. Maesa lanceolata and E. croceum had good TAA, with values at $5562 \mathrm{ml} / \mathrm{g}$ and $1125 \mathrm{ml} / \mathrm{g}$. All the extracts had low SI values. Cock and van Vuuren [34], reported that methanol and water extracts of Carpobrotus edulis, Lippia javanica, Pelargonium viridflorum, Ptaeroxylon obliquum, Syzygium cordatum leaf and bark, Terminalia pruinoides, Terminalia sericea, Warburgia salutaris bark and an aqueous extract of W. salutaris leaf had some activity Proteus inhibitors, with MIC values $<2 \mathrm{mg} / \mathrm{ml}$. Our results are in same order as their results.

\section{Enterobacter cloacae}

Enterobacter is an increasingly important human pathogen, particularly in the hospital setting. Enterobacter accounts for 5 to $11 \%$ of all nosocomially-transmitted blood, wound, respiratory tract, and urinary tract infections [35]. Enterobacter is responsible for between 4 and $12 \%$ of all cases of Gram-negative bacteraemia. All age groups are affected. In adults, Enterobacter is the third or fourth leading cause of sepsis after Escherichia coli, Klebsiella spp., and Pseudomonas aeruginosa. All the extracts had reasonable activity against Enterobacter cloacae, with MICs ranging between 0.08 and $0.31 \mathrm{mg} / \mathrm{ml}$ (Table 2). Maesa lanceolata and E. croceum had good TAA with values at $1390 \mathrm{ml} / \mathrm{g}$ and $1125 \mathrm{ml} / \mathrm{g}$ respectively. The susceptibility of Enterobacter cloacae has previously been reported by Shiri et al. [35] when tested against ethanol leaf extracts of Peganum harmal and Myrtus communis respectively.

\section{Escherichia coli}

All tested extracts generally, had good activity against Escherichia coli egg isolate. MIC values ranged between 0.08 to $0.16 \mathrm{mg} / \mathrm{ml}$. Makhafola and Eloff [36] reported a similar trend when E. coli (ATCC 25922) was treated with the extracts from different Ochna spp. Hypericum roeperianum and E. croceum extracts had a very good TAA, with values of $1500 \mathrm{ml} / \mathrm{g}$ and $1125 \mathrm{ml} / \mathrm{g}$ respectively. Heteromorpha arborescens had the best SI $=1.01$ (Table 2). Maesa lanceolata and $E$. croceum extracts had poor selectivity index values (Table 2). The mean MIC values of the extracts against the egg isolates ranged from $0.14 \mathrm{mg} / \mathrm{ml}$ to $0.34 \mathrm{mg} / \mathrm{ml}$ (Tables 1 and 2 and Fig. 1). Calpurnia aurea had the lowest mean MIC value of $0.14 \pm$ $0.09 \mathrm{mg} / \mathrm{ml}$, and M. mesozygia had the highest mean value of $0.34 \pm 0.41 \mathrm{mg} / \mathrm{ml}$ (Table 2).

In general, extracts of $C$. aurea had good activity against all the tested egg isolates, while extracts of $M$. mesozygia had the lowest activity. Cremaspora triflora had good activity against five out of the six pathogens with an MIC of $0.08 \mathrm{mg} / \mathrm{ml}$ each, except against Proteus mirabilis, were the extract had a moderate activity with (MIC $0.63 \mathrm{mg} / \mathrm{ml}$ ) (Table 1 and 2). The outstanding activity of $C$. triflora extracts suggests that the plant has potential as a promising therapeutic agent against some members of the Enterobacteriaceae. Further pharmacological investigations might be required in the search for new antimicrobial leads. Also of note are the extracts of $H$. arborescens and $P$. viridiflorum with mean MIC values against all the isolates of $0.16 \mathrm{mg} / \mathrm{ml}$ (Fig. 2); they both had similar activity against $P$. mirabilis which also makes them potential candidates for further evaluation.

Cremaspora triflora is the best plant extract for investigation because very little work has been carried out on this plant species, thus giving it some novelty. Overall $E$. coli was the most sensitive pathogen to all nine extracts (mean $\mathrm{MIC}=0.08 \pm 0.08 \mathrm{mg} / \mathrm{ml}$ ), while Proteus mirabilis was the most resistant with mean MIC values of $0.46 \pm 035 \mathrm{mg} / \mathrm{ml}$ (Table 2 and Fig. 1).

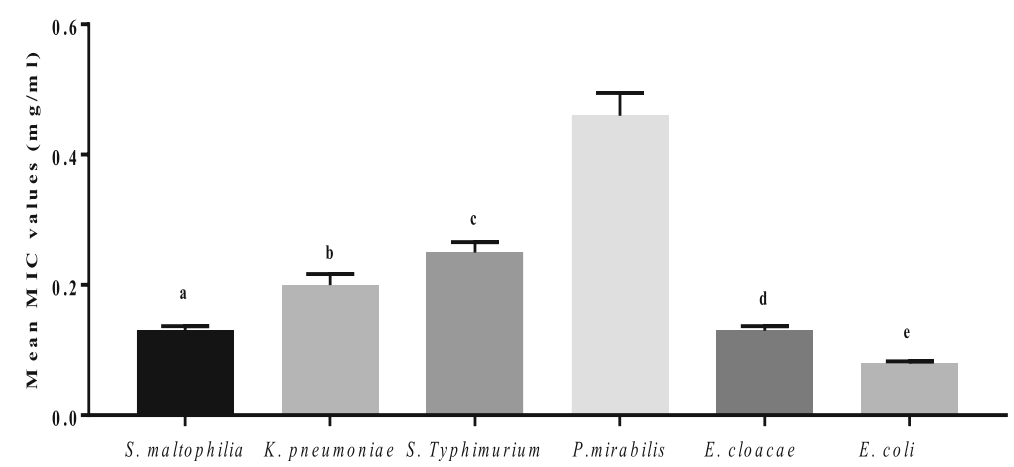

Fig. 1 Sensitivity of the six pathogenic egg isolates to the nine selected acetone leaf extracts. Legend: $a, b, c, d$ and ${ }^{e}=$ statistically significant difference in the mean MIC of the pathogens, $p<0.05$ 


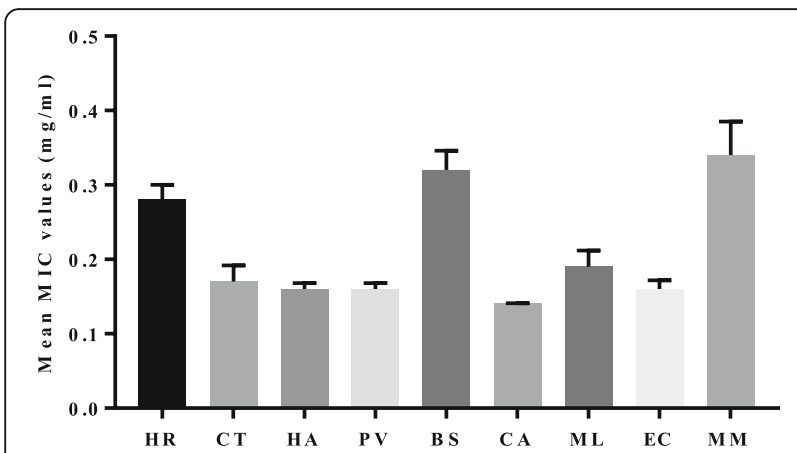

Fig. 2 Mean minimal inhibitory concentration of the nine selected acetone leaf extracts tested against six opportunistic bacterial pathogens isolated from commercial eggs. Legend: $\mathrm{HR}=$ Hypericum roeperianum, $\mathrm{CT}=$ Cremaspora triflora, $\mathrm{HA}=$ Heteromorpha arborescens, $\mathrm{PV}=$ Pittosporum viridiflorum, $\mathrm{BS}=$ Bolusanthus speciosus, $\mathrm{CA}=$ Calpurnia aurea, $\mathrm{ML}=$ Maesa lanceolata, $\mathrm{EC}=$ Elaeodendron croceum, MM = Morus mesozygia. The mean difference of the nine acetone leaf extracts were not statistically significant, $p>0.05$

\section{Conclusions}

The extracts had varying degrees of activity against the pathogens isolated from commercial eggs. Cremaspora triflora extracts however, had exceptional activities, against all the pathogenic egg isolates except against Proteus mirabilis. The promising antibacterial activities and selectivity index of the extracts of $C$. triflora against all test pathogens makes it the good candidate for more detailed pharmacological and biological investigations. If products developed from $C$. triflora extracts are not harmful to humans, it could play a role in enhancing food safety for example by washing the outside of the eggs with an extract before cooking.

\section{Abbreviations}

AJ: Alexander Jambalang.; MIC: Minimum inhibitory concentration; NA: Not applicable; TAA: Total antibacterial activity

\section{Acknowledgements}

The curators of the Pretoria National Botanical Gardens, the Lowveld National Botanical Gardens in Nelspruit and the University of Pretoria Botanical Garden allowed us to collect plant material.

\section{Funding}

This manuscript is an output of a Ph. D. research project supported by the National Research Foundation of South Africa (Eloff IPPR 953991) the South African Medical Research Council and the University of Pretoria.

\section{Availability of data and materials}

Plant material was collected in botanical gardens and materials were purchased from commercial suppliers.

\section{Authors' contributions}

ILE carried out the research and wrote the first draft of the manuscript. ARJ isolated the pathogenic test bacteria from commercial eggs and revised the manuscript. FSB assisted in the research work and revised the manuscript. EMB assisted in identification of Salmonella by using PCR, LUM made substantial contributions in revising the manuscript. JNE identified the project, guided the research, finally revised and submitted the manuscript. All authors have read and approved the final version of the manuscript.

\section{Competing interests}

We declare that we have no financial or competing interests, which may have inappropriately influenced us in writing this article.

\section{Consent for publication}

No consent for publication is involved in this study.

Ethics approval and consent to participate

Because no animals or humans were used in this study no ethical approval or consent to participate was required.

\section{Author details}

${ }^{1}$ Phytomedicine Programme, Department of Paraclinical Sciences, Faculty of Veterinary Science, University of Pretoria, Private Bag X04, Onderstepoort, 0110 Pretoria, South Africa. ${ }^{2}$ Permanent address: Drug Development Section, Biochemistry Division, National Veterinary Research Institute, P.M.B. 01 Vom, Plateau State, Nigeria, South Africa. ${ }^{3}$ Permanent address: Bacterial Research Division, National Veterinary Research Institute, P.M.B. 01 Vom, Plateau State, Nigeria, South Africa. ${ }^{4}$ Department of Food Science, University of Pretoria, Pretoria, South Africa.

Received: 11 November 2016 Accepted: 21 January 2017

Published online: 02 February 2017

\section{References}

1. Adesiyun A, Offiah N, Seepersadsingh N, Rodrigo S, Lashley V, Musai L. Frequency and antimicrobial resistance of enteric bacteria with spoilage potential isolated from table eggs. Food Res Int. 2006;39:212-9.

2. Jambalang AR. The development and validation of a bacteriological screening test for antimicrobial residues in eggs. MSc Dissertation. South Africa: University of Pretoria; 2011. http://hdl.handle.net/2263/24843.

3. Al-Ashmawy MA. Prevalence of Enterobacteriaceae in table eggs with particular reference to enterovirulent Escherichia coli strains. Int J Poult Sci. 2013;12:430-5.

4. Messens W, Grijspeerdt K, Herman L. Eggshell penetration by Salmonella : a review. Worlds Poult Sci J. 2005:61(March):71-86.

5. Adesiyun A, Offiah N, Seepersadsingh N, Rodrigo S, Lashley V, Musai L. Antimicrobial resistance of Salmonella spp. and Escherichia coli isolated from table eggs. Food Control. 2007;18:306-11.

6. Musgrove MT, Northcutt JK, Jones DR, Cox NA, Harrison MA. Enterobacteriaceae and related organisms isolated from shell eggs collected during commercial processing. Poult Sci. 2008;87:1211-8.

7. Sabarinath A, Guillaume V, Guillaume B, Mathew V, DeAllie C. Bacterial contamination of commercial chicken eggs in Grenada. West Indies. West Indian Vet J. 2009:9(December):4-7.

8. Andersson DI, Hughes D. Persistence of antibiotic resistance in bacterial populations. FEMS Microbiol Rev. 2011:35:901-11.

9. Palaniappan K, Holley R. Use of natural antimicrobials to increase antibiotic susceptibility of drug resistant bacteria. Int J Food Microbiol. 2010;140:164-8.

10. Bonjar G. Screening for antibaterial properties of some Iranian plants against two strains of Escherichia coli. Asian J Plant Sci. 2004:3:310-4.

11. Pauw E. Evaluating the taxonomic relationships between 537 southern African tree species and their antimicrobial activity against six important fungal and bacterial pathogens. In: PhD thesis, Faculty of Veterinary Science. South Africa: Universiry of Pretoria; 2014.

12. Elisha IL, Dzoyem JP, Botha FS, Eloff JN. The efficacy and safety of nine South African medicinal plants in controlling Bacillus anthracis Sterne vaccine strain. BMC Complement Altern Med. 2016;16:5.

13. Kotze M, Eloff JN. Extraction of antibacterial compounds from Combretum microphyllum (Combretaceae). S Afr J Bot. 2002;68:62-7.

14. Eloff JN, Masoko P, Picard J. Resistance of animal fungal pathogens to solvents used in bioassays. S Afr J Bot. 2007;73:667-9.

15. Mellman A, Cloud J, Keckevoet U, Ramminger I, Iwen P, Dunn I, Hall G, Wilson D, LaSala P, Kostrzewa M, Harmsen D. Evaluation of matrix-assisted laser desorption ionization-time-of-flight mass spectrometry in comparison to $16 \mathrm{~s}$ rRNAgene sequencing identification of non-fermenting bacteria. J Clin Microbiol. 2008;46:1945-54.

16. WHO: Laboratory Protocol "isolation of Salmonella Spp. from Food and Animal Faeces." 5th edition. WHO; 2010. 
17. Eloff JN. A sensitive and quick microplate method to determine the minimal inhibitory concentration of plant extracts for bacteria. Planta Med. 1998;64:711-3

18. Mosmann T. Rapid colorimetric assay for cellular growth and survival: application to proliferation and cytotoxicity assays. J Immunol Methods. 1983;65:55-63.

19. Eloff JN. Quantification the bioactivity of plant extracts during screening and bioassay guided fractionation. Phytomedicine. 2004;11:370-1.

20. Ríos JL, Recio MC. Medicinal plants and antimicrobial activity. J Ethnopharmacol. 2005;100:80-4.

21. Aro AO, Dzoyem JP, Hlokwe TM, Madoroba E, Eloff JN, McGaw LJ. Some South African Rubiaceae Tree Leaf Extracts Have Antimycobacterial Activity Against Pathogenic and Non-pathogenic Mycobacterium Species. Phytother Res. 2015;29:1004-10.

22. Pauw E, Eloff JN. Which tree orders in southern Africa have the highest antimicrobial activity and selectivity against bacterial and fungal pathogens of animals? BMC Complement Altern Med. 2014;14:317.

23. Sanchez JGB, Kouznetsov W. Antimycobacterial susceptibility testing methods for natural product research. Braz I Microbiol. 2010;41:270-7.

24. Eloff JN. On expressing the antibacterial activity of plant extracts - a small first step in applying scientific knowledge to rural primary health care. S Afr J Sci. 2000:96:116-8.

25. Kuete V. Potential of Cameroonian plants and derived products against microbial infections: A review. Planta Med. 2010;76:1479-91.

26. Sharma AK, Kumar A, Yadav SK, Rahal A. Studies on Antimicrobial and Immunomodulatory Effects of Hot Aqueous Extract of Acacia nilotica $\mathrm{L}$. Leaves against Common Veterinary Pathogens. Vet Med Int. 2014;2014:747042

27. Gordon NC, Wareham DW. Antimicrobial activity of the green tea polyphenol (-)-epigallocatechin-3-gallate (EGCG) against clinical isolates of Stenotrophomonas maltophilia. Int J Antimicrob Agents. 2010;36:129-31.

28. WHO. Global Tuberculosis Report 2015. 20th ed. France: WHO Press; 2015.

29. Fennell CW, Lindsey KL, McGaw LJ, Sparg SG, Stafford Gl, Elgorashi EE, Grace $\mathrm{OM}$, Van Staden J. Assessing African medicinal plants for efficacy and safety: Pharmacological screening and toxicology. J Ethnopharmacol. 2004;94:205-17.

30. Bodenstein J, Du Toit K: The Susceptibility of Staphylococcus aureus and Klebsiella pneumoniae to Naturally Derived Selected Classes of Flavonoids. In Antimicrobial Agents. Edited by Varaprasad Bobbarala. InTech; 2011:73-84.

31. Sá MB, Ralph MT, Nascimento DCO, Ramos CS, Barbosa IMS, Sá FB, LimaFilho JV. Phytochemistry and Preliminary Assessment of the Antibacterial Activity of Chloroform Extract of Amburana cearensis (Allemão) A.C. Sm. against Klebsiella pneumoniae Carbapenemase-Producing Strains. Evid Based Complement Alternat Med. 2014:2014:786586

32. Shaik G, Sujatha N, Mehar SK. Medicinal plants as source of antibacterial agents to counter Klebsiella pneumoniae. J Appl Pharm Sci. 2014;4:135-47.

33. Hur J, Jawale C, Lee JH. Antimicrobial resistance of Salmonella isolated from food animals: A review. Food Res Int. 2012:45:819-30.

34. Cock IE, Van Vuuren SF. Anti-Proteus activity of some South African medicinal plants: Their potential for the prevention of rheumatoid arthritis. Inflammopharmacology. 2014;22:23-36.

35. Shiri Y, Solouki M, Saeidi S. Activity of some Iranian plant extracts against Multi-Drug Resistant human pathogens isolated from urinary tract infections. Zahedan J Res Med Sci. 2014;16:50-4.

36. Makhafola TJ, Eloff JN. Five Ochna species have high antibacterial activity and more than ten antibacterial compounds. S Afr J Sci. 2012;108(1/2):1-6.

\section{Submit your next manuscript to BioMed Central and we will help you at every step:}

- We accept pre-submission inquiries

- Our selector tool helps you to find the most relevant journal

- We provide round the clock customer support

- Convenient online submission

- Thorough peer review

- Inclusion in PubMed and all major indexing services

- Maximum visibility for your research

Submit your manuscript at www.biomedcentral.com/submit

C Biomed Central 